\title{
ASPECTS OF THE IRAN-UNITED STATES CLAIMS TRIBUNAL*
}

\author{
Allahyar Mouri * *
}

\section{INTRODUCTION}

On 4 November 1979 the United States Embassy in Tehran was invaded by a group of university students who were among people protesting in the street outside the compound against the United States' policies towards the Iranian revolution. The students later identified themselves as "Muslim Students Followers of the Imam's Line". It is this event which gave rise to what came to be known as the "hostage crisis".

Ten days later, on 14 November 1979, Mr. BANISADR, then minister in the Government of the Islamic Republic of Iran with Finance and Foreign Affairs portfolios, ${ }^{2}$ issued a statement suggesting the possible withdrawal of multi-billion dollar deposits with the United States banks. This somewhat provocative and unnecessary statement was considered sufficient justification for the United States Government, acting through its executive branch, to freeze assets and properties belonging to Iran, its organizations and entities, including its central bank and other banking institutions, which were within US territory or under the control of US nationals or bankers throughout the world, under the excuse of protecting the stability of the US dollar. ${ }^{3}$ Without the occurrence of the embassy

\footnotetext{
* This article was completed in May 1992.
}

** Legal Assistant to the Iran-United States Claims Tribunal; former Principal Counsel to the National Iranian Oil Company and its affiliated companies.

1. See, e.g., ICJ Judgement in The Case concerning United States Diplomatic and Consular Staff in Tehran (United States of America $v$. Iran), ICJ Rep. 1980, p. 3 et seq.

2. Mr. BANI SADR was the first President elected to the Islamic Republic of Iran. He fled the country after failing in struggles over power.

3. See R. BALL, "The unseemly squabble over Iran's assets", Fortune, $28 \mathrm{Jan} .1980$, at 61 ; New York Times, 15 Nov. 1979, at 1 , and R. HIGGINS, "The taking of property by the State: recent developments in international law"; 176 RdC (1982-II) p. 259, at 283-284.

\section{1}

Ko Swan Sik et al. (eds.), Asian Yearbook of International Law, Volume 2, $61-85$

(C) 1994 Kluwer Academic Publishers. Printed in the Netherlands 
event it is unlikely that the Executive Branch would have been successful in freezing and maintaining the freeze of well over 12 billion dollars worth of Iranian assets and properties, including cash, military and non-military properties. Records indicate that Executive Order No. 12.170 of 14 November $1979,{ }^{4}$ the first of a series of freezing orders, was actually prepared under pressure brought to bear on President CARTER by bankers and multi-national companies well ahead of Mr. BANISADR'S assertion. ${ }^{5}$

Soon after Mr. BANI-SADR'S statement, Mr. ALI REZA NOBARI, then Governor of Bank Markazi (Iran's Central Bank) denied any intention to withdraw Iranian assets, ${ }^{6}$ and the Iranian government officially and publicly confirmed Mr. NOBARI's announcement. ${ }^{7}$ In addition, it was widely believed that the new Iranian Government had every intention and desire to meet its obligations under the loan agreements, thus weakening the justification for President CARTER's freeze. ${ }^{8}$

As legal justification for the freeze, President CARTER resorted to provisions of United States regulations, including the International Emergency Economic Powers Act $^{9}$ and the National Emergency Act. ${ }^{10}$ In principle, these laws only permit the President to act to protect the "national security" of the United States. As there was to be no withdrawal of funds by Iran (and even if a withdrawal was imminent it could not have been considered a threat to the national security, foreign policy and economy of the United States) the legal authority of the President's action in this case, particularly in respect of the Iranian assets frozen outside the U.S. is open to question. ${ }^{11}$

Over time, freeze orders were made covering even more Iranian assets and properties and limiting, as much as possible, Iran's control over them. At the same time, Executive Orders allowed claims, attachments and injunctions to be brought by United States nationals against Iran in

4. 44 Fed. Reg. 65,729 (1979), reprinted in: 3 C.F.R. 457 (1981); 74 AJIL (1980), p. 428; A.F.

LOWENFELD, Trade Controls for Political Ends, Vol. III (2nd ed., 1983) p. 546-547; and 13 Lawyer of the Americas (University of Miami Journal of International Law) A-61.

5. See: "Escalating the Iranian drama", Business Week, 26 Nov. 1979, p. 31; E. GORDON, "Trends, the blocking of Iranian assets", 14 The International Lawyer (1980), p. 659, at 660-661 and 671; and LOWENFELD, op.cit., p. 548 et seq.

6. R. BALL, op.cit. n. 3; and LOWENFELD, op.cit. n. 4, p. 550 and note d.

7. The Wall Street Journal, 3 Dec. 1979, at 2, 10.

8. "Legal repercussions of the freezing of Iranian assets and loans", 12 International Currency Review (1980) 25, 27.

9. 50 U.S.C., Section 1701 et seq. (1977); Pub. L. 95-223, 91 Stat. 1625 (28 Dec. 1977); see also LOWENFELD, op.cit. n. 4, DS. 729 et seq., and GORDON, op.cit. n. 5, 662 et seq.

10. 50 U.S.C. Section 1601 et seq.

11. Iran: The Financial Aspects of the Hostage Settlement Agreement III-IV (Staff of House Comm. on Banking, Finance and Urban Affairs, 97th Cong., 1st Session), at Pp. 3-5, 12 and 43; RICHARD W. EDWARDS, Jr., "Extraterritorial application of the U.S. Iranian assets control regulations", 75 AJIL (1981) pp. 870, 871 and note 8 thereof, and R. HIGGINS, loc.cit. n. 3, p. 283. 
respect of its assets and properties in the United States and elsewhere, giving rise to the filing of hundreds of court actions and requiring Iran and Iranian entities to defend themselves all over the world - with very little hope, if any, of success in protecting their rights and interests. ${ }^{12}$

\section{THE ALGIERS DECLARATIONS}

After Ayatollah KHOMEINI'S personal intervention on 12 September 1980 by announcing four conditions for a final resolution of the political issue, and after adoption of these conditions in a resolution passed by Iran's Islamic Consultative Assembly (Iran's "Parliament" or "Majles") on 2 November $1980,{ }^{13}$ indirect negotiations started between delegates of the Government of Iran and of the United States through mediation of the Government of Algeria. ${ }^{14}$ As a result, on 19 January 1981 two documents which came to be known as the "Algiers Declarations" or "Algiers Accords" were adhered to by the Governments of Iran and the United States. The first is entitled simply "Declaration of the Government of the Democratic and Popular Republic of Algeria", and is usually referred to as the "General Declaration"; the second is the "Declaration of the Government of the Democratic and Popular Republic of Algeria concerning the Settlement of Claims by the Government of the United States and the

12. See, e.g., LOWENFELD, op.cit. n. 4, 579 et seq.

13. This resolution constituted the basis of the following negotiations and is referred to in the preamble to the General Declaration (see infra) as the framework within which the crisis was to be resolved (1 Iran-U.S. CTR 3). The resolution required, in essence, that the United States should: (i) refrain from interfering, directly or indirectly, in the internal affairs of Iran; (ii) nullify all presidential orders which froze Iranian assets and guarantee the free transfer of such properties; (iii) cancel and annul all economic, financial and legal actions, including claims, against Iran and Iranian properties; and (iv) take all legal and administrative actions necessary to transfer the properties of the deceased Shah to Iran. For the full English translation of Ayatollah KHOMEINl's four conditions and the Majles Resolution, see LOWENFELD, op.cit. $n$. 4, pp. 587-588 and DS-809.

14. The fact that the Algiers Declarations were not able to achieve entirely what the Majles Resolution intended to achieve is not denied by either of the two Governments. Iran has almost constantly, from the inception of the work of the Tribunal, accused the Government of the United States of being in breach of the Algiers Declarations, both in interpretative disputes (categorized as " $A$ " Cases; including Case $A / 15$ which encompasses the major part of such claims) and in "official claims" (i.e., "claims of the United States and Iran... arising out of the contractual arrangements between them for the purchase and sale of goods and services", categorized as " $B$ " Cases), subject matter of para. 2 of Art. II of the Claims Settlement Declaration - see infra. In almost all these cases the Majles Resolution forms the corner stone of the Iranian arguments, paras 51-52 of Partial Award No. 282-B1 (Claim 4)-FT (19 Iran-U.S. CTR 273) and ITL 78-A/15(I-C)-FT, in The Islamic Republic of Iran and United States of America, reprinted in IALR, May 1992, p. 20849. The position of the United States Government in all such cases has always been that although the November Resolution of the Majles formed the basis of the negotiations towards the resolution of the crisis, the Declarations are the fruit of those efforts achieved with the mediation of the Algerian representatives, and any obligation should be understood within the frame-work of the Accords. 
Islamic Republic of Iran", often called the "Claims Settlement Declaration". ${ }^{\prime 15}$

The Accords are different from normal treaties. They were declarations made by the Algerian Government and "adhered to" by the Governments of Iran and the United States of America. Ratification was not made a requirement for their international effect, and they were not ratified by the United States Senate or the Iranian Majles. The international validity of the Accords has not been questioned, though some controversy exists about their validity under the internal law of the contracting States. The present paper will not deal with this aspect of the Declarations. However, evidence of their approval and validity in US law are to be found in President CARTER'S Executive Orders which were issued simultaneously with the United States' "Statement of Adherence" to the Declarations and were made part of the Accords, ${ }^{16}$ and later in Executive Order No. 12294 issued by President REAGAN on 24 February $1981 .{ }^{17}$ The authority of the Executive Branch to enter into the Accords was eventually upheld by the United States Supreme Court in Dames and Moore v. Reagan. ${ }^{18}$ As to the internal law of Iran, the matter is not as clear as is the case with the United States. The Iranian Constitution requires the Majles to ratify all international agreements ${ }^{19}$ and all settlements of governmental disputes or their referral to arbitration. ${ }^{20}$ Those who argue against the validity of the Accords contend that the Iranian negotiators had no authority to agree on arbitration without the specific approval of the Majles, and that in so doing they contravened Principle 139 of the Constitution. ${ }^{21}$ Those arguing in favour of the Accords' validity refer to the Single Article Act

15. For the complete texts of these Declarations, see, e.g., 1 Iran-U.S. CTR, 3, 9; 20 ILM (1981) 224, 230; 75 AJIL (1981) pp. 418, 422; A. LOWENFELD, op.cit. n. 4, DS-823 and DS-829; 13 Lawyer of the Americas, op.cit. n. 4, A-28 to A-39; and 7 Droit et Pratique du Commerce International (1981) 716,722 .

16. 46 Fed. Reg. 7913-7927 (1981); 3 C.F.R. 104-118 (1982), reprinted in U.S.C. Sec. 1701 at 150151 (1982); and LOWENFELD, op.cit. n. 4, DS-850 to DS-869.

17. 46 Fed. Reg. 14,111 (1981); 3 C.F.R. 139-40 (1982) reprinted in 50 U.S.C. Sec. 1701 at 155 , and LOWENFELD, op.cit. n. 4, DS-872. In order to determine whether the Government of the United States did breach certain provisions of the Accords by unilaterally altering the undertakings through President REAGAN's Executive Order, a separate thorough evaluation and analysis of the provisions of the Accords, and of President CARTER's and President REAGAN'S Executive Orders is required. For a brief analysis of those documents, see ITL 78-A/15(1-C)FT, supra n. 14.

18. 453 U.S. 654 (1981)

19. Principle 77 of the Iran's Constitution provides: "International treaties, protocols, contracts and agreements must be ratified by the Islamic Consultative Assembly".

20. Principle 139 of Iran's Constitution prescribes: "Settling of claims relating to public and State property or referral thereof to arbitration is in any case subject to the approval of the Council of Ministers, and the Assembly must be informed. In cases where one party to the claim is a foreigner, as well as in important domestic cases, the approval of the Majles must also be obtained. The law shall determine important cases". 
"Concerning the Settlement of the Financial and Legal Disputes of the Government of the Islamic Republic of Iran with the Government of America" 22 and to Article 27 of the 1969 Vienna Convention on the Law of Treaties. $^{23}$

\section{THE TRIBUNAL'S JURISDICTION}

The Algiers Declarations established a Tribunal to settle certain disputes existing between the Governments on the date that the Declarations were adhered to. Apart from the social, political and economic ramifications of the events which ended in the issuance of the Declarations and the creation of the Tribunal (which fall outside the scope of this article), ${ }^{24}$ the Algiers Declarations, in particular the "Claims Settlement

21. In this connection, see, e.g., the dissenting opinion of SHAFIE SHAFIEI in Phillips Petroleum Company and Iran and Amoco Iran Oil Company and Iran, Interlocutory Awards Nos. 11-39-2 and 12-55-2, 3 Iran-U.S. CTR 297, 305-308.

22. The Law provided: "The Government is authorized, subject to observance of the provisions approved by the Islamic Consultative Assembly, to take steps by means of consensual arbitration to settle the financial and legal disputes between the Government of the Islamic Republic of Iran and the Government of the United States of America which did not arise out of the Islamic Revolution of Iran and the seizure of the Centre of the American plotting".

Note: Disputes, the settlement of which by competent Iranian tribunals has been provided in the respective contract, are excluded from being subject to this Single Article Act. (For a different translation, see LOWENFELD, op.cit. n. 4, p. 590 note "A").

The contemporaneous records of the Majles public debates during January 1981 (especially the debates on 13 and 14 January)show that in authorizing the Government, the members of the Majles expected that permission for every single case would be sought as provided by the provisions of Principle 139, op.cit. n. 20. In any event, it should be emphasized that both Iran and the United States treated the Algiers Declarations as constituting a treaty under international law (see: dissenting opinion of MAHMOUD M. KASHANI, SHAFIE SHAFIEI and SEYYED HOSSEIN ENAYAT, Case A/2, 1 Iran-U.S. CTR, 104, 109; decision of the Full Tribunal in Case A/ 1, Issue I (30 July 1982), ibid. p. 189; decision of the Full Tribunal in $A / 18,5$ Iran-U.S. CTR, 251, 259; and dissenting opinion of the Iranian arbitrators to the same decision at 279 et seq).

23. See, e.g., Judge BELLET's reasoning "on the First Point" in Phillips Petroleum Company and Iran (TTL 11-39-2) and Amoco Iran Oil Company and Iran (TTL 12-55-2) in 1 Iran-U.S. CTR, pp. 487 and 493 respectively. It should be noted that Art. 27 of the Vienna Convention which prohibits the invocation of a provision of internal law "as justification for... failure to perform" under a valid treaty cannot resolve the issue of the validity or lack of authority to enter into a treaty. (For the Vienna Convention, see U.N. Doc. A/CONF.39/27 (23 May 1969); also in 8 ILM (1969) p. 679).

24. "The occupation of the United States Embassy compound in Tehran was considered necessary to prevent the re-occurrence of what was engineered from those premises in 1953." (dissenting opinion of the Iranian Arbitrators in the interpretive A/18 Case, (cit. n. 22, 275276). This is a reference to a coup d'état which the CIA admitted to have engineered to overthrow the then national government of Iran, which had nationalized the Iranian oil industry three years prior to the event. See KERMIT ROOSEVELT, Countercoup, the Struggle for the Control of Iran (1979); RICHARD W. COTTAM, Nationalism in Iran (1979); HOMA KATOUZIAN, The Political Economy of Modern Iran (1981); C. M. WOODHOUSE, Something Ventured (1982); BRIAN LAPPING, End of Empire (1985)). The event has also been considered by some learned scholars from a legal point of view as a legitimate act of self-defence. See in this connection, FRANCIS ANTHONY BOYLE, World Politics and International Law, pp. 182-203. 
Declaration", created a unique venue for adjudication of a large number of commercial and contractual claims of United States nationals. The purpose of establishing the Tribunal is generally considered to have been "to terminate all litigation as between the Government of each party and the nationals of the other, and to bring about the settlement and termination of all such claims through binding arbitration. ${ }^{25}$

Before deciding a case, the Tribunal must satisfy itself, ex officio, that it has jurisdiction over the particular claim before it, even if a party raises no jurisdictional objection. The Full Tribunal has stated that "it is an undisputed fact that the extent of the Tribunal's jurisdiction has been determined by Iran and the United States in the Algiers Declarations, which contain detailed provisions on the jurisdiction of the Tribunal, and that, consequently, the Tribunal has no jurisdiction over any matter not conferred on it by these Declarations" ${ }^{26}$ Moreover, Chamber One and Chamber Three of the Tribunal have stated more specifically that "the Tribunal holds that it has to determine ex officio whether it has jurisdiction in [a] case" before it. ${ }^{27}$

The Tribunal's jurisdiction, more specifically defined and delineated by the Claims Settlement Declaration ("CSD"), is restricted from various perspectives and subject to various exceptions. From the point of view of personal jurisdiction (ratione personae) recourse to the Tribunal is restricted to the nationals of Iran and the United States, ${ }^{28}$ and to the claims of both Governments against each other. While claims of nationals of one State against the other State are considered to be within the jurisdiction of the Tribunal, claims of either of the two Governments against nationals of the other are considered admissible only if they are raised and formulated by way of counterclaim. ${ }^{29}$

25. For the text of "Principle B" of the General Declaration, see the sources referred to in $n$. 15 supra. The provisions of "Principle B" have been among the many contentious provisions of the Accords, especially from the point of view of admissibility of claims and the obligation of the United States to vacate or annul court proceedings, attachments and injunction orders in the United States. Case A/15 (IV) is concerned with the interpretation of a part of this principle. Moreover, Iran interpreted this provision as limiting the jurisdiction of the Tribunal to those claims already put forward or filed with adjudicative bodies. Iran relied on the words "litigating" and "legal proceedings" used in "Principle B", the Majles' position (supra n. 13) and the travaux préparatoires in support of its interpretation. See also SHAFIE SHAFIEI (dissenting opinion) cit. n. 21 , p. 310 et seq.

26. Case A/1, 1 Iran-U.S. CTR 11, 152.

27. Award No. 106-B/24-1 (The United States of America and the Islamic Republic of Iran), 5 IranU.S. CTR 97, 99, and Award No. 275-12783-3 in Parguin Private Joint Stock Company (a claim of less than US $\$ 250,000$, presented by Iran), ibid. vol. 13, pp. 261, 263. See also Marks and Harry Umann and Islamic Republic of Iran, (ITL 53-458-3), ibid. vol. 8, 290 at 296-297; Orton/McCullough Crane Company and Iranian State Railways, Bank Markazi Iran (Award No. 484-440-3 para. 7), ibid. vol. 25 p. 17 and ITEL International Corp. and the Social Security Organization et al (Award 479-476-2 para. 31) ibid. vol. 24 p. 281. 
In analyzing the Tribunal's personal jurisdiction, the legal personality of the respondents also plays an important role. Thus, even though claims of nationals of each high contracting party are considered admissible, such claims would not fall within the Tribunal's jurisdiction if they are not against either one of the two Governments, any political subdivision, agency, or instrumentality thereof, or any entity controlled by either of the Governments or any of their political subdivisions. ${ }^{30}$

The Tribunal's jurisdiction is further restricted to claims that had arisen prior to the date the Algiers Accords entered into force, 19 January 1981 , and that were outstanding on that date (ratione temporis). In the Tribunal's view, the requirements for a claim to be outstanding within the meaning of Article II, paragraph 1 of the CSD vary, according to the cause of action. The Tribunal has, in expropriation cases, generally considered a claim to be outstanding from the date the measure or act affecting the property or property rights took place. A contract or debt claim is considered to be outstanding from the date the services were rendered or goods were delivered and payment was due, or when a debt matured, regardless of whether a demand was made or a proceeding instituted prior to 19 Jan-

28. Art. VII of the CSD (supra n. 15) provides that:

"For the purpose of this Agreement: A national of Iran or the United States, as the case may be, means (a) a natural person who is a citizen of Iran or the United States; and (b) a corporation or other legal entity which is organized under the laws of Iran or the United States or any of its states, territories, ... if, collectively, natural persons who are citizens of such country hold, directly or indirectly, an interest in such corporation or entity equivalent to fifty percent or more of its capital stock."

See, inter alia, Aeromaritime, Inc. and the Government of the Islamic Republic of Iran (Award No. 2-373-2) 1 Iran-U.S. CTR 135; General Atomic Co. and Atomic Energy Organization (Award No. 12-281-3), ibid. p. 223; Hawaiian Agronomics Co. (Refusal Case No. 10) ibid. p. 138; and Raymond International (U.K.) Ltd. (Refusal Case No. 20) ibid. p. 394.

29. See Article II (1), page 69 infra. It appears that the Iranian negotiators did not have the technical meaning of the concept of "counterclaim" in mind when they negotiated the CSD. While "[s]uch a right of counterclaim is normal for a respondent" and is recognized and well defined, with almost no exception, by legal systems all over the globe, the use of the word does not mean that "by analogy, $[\ldots .$.$] each State is allowed to submit claims against nationals$ of the other State." (Decision 1-A/2-FT in interpretative Case A/2, Iran-U.S. CTR 101, 103.) As a result Iran was deprived of the opportunity to raise most of the claims it had in mind when it adhered to the Algiers Declarations. The cost of such a simple mistake was enormous, because, in contrast to the fact that there were thousands of pending or potential claims against Iran as defined in Article VII (3) of the CSD, few Iranian nationals, if any, could have thought of any claim against the United States, as defined by paragraph 4 of the same Article, due to the very nature of the relations between the two governments and of each government with the nationals of the other. As a result, about 1330 Statements of Claim were withdrawn by Iran after the Full Tribunal's Decision in Case $A / 2$. These claims, so far as they were raised as counterclaims, were finally rejected, either based on the ground that they were unrelated to the contracts in dispute, or because they were not between the same parties. See also the Full Tribunal's decisions in cases $A / 16$ and $A / 17$, Nos. 108-A-16/582/591-FT and 37-A17-FT, 5 and 8 Iran-U.S. CTR 58 and 189, respectively, whereby about 350 banking claims were also dismissed for lack of jurisdiction based on arguments similar to those relied upon by the Full Tribunal in Decision 1/A/2-FT.

30. See Article VII (3) and (4) of the CSD. 
uary $1981 .{ }^{31}$ On the other hand, the Tribunal has found in banking disputes (such as claims related to withdrawals and transfers from bank accounts or demands under bank guarantees) that the mere right to payment from a bank account does not constitute an outstanding claim and that a demand for payment must have been made prior to the jurisdictional date. ${ }^{32}$ Interpretative claims and claims for performance of the Accords or in respect of breach of obligations undertaken pursuant to the Declarations themselves ${ }^{33}$ are by their nature excepted from the ratione temporis limitation. ${ }^{34}$

There is also a procedural time bar to the jurisdiction of the Tribunal created by Article III(4) of the CSD, which required the filing of any claim within one year after the CSD entered into force. The Declarations were adhered to on 19 January 1981; consequently, claims not filed by 19 January 1982 were considered time barred, regardless of whether they would satisfy the other jurisdictional requirements. ${ }^{35}$ In a matter of three months (from 19 October 1981 to 19 January 1982) a total of 3,816 claims

31. See, e.g., ITL 11-39-2 and ITL 12-55-2, op.cit. n. 23 pp.487 and 493, respectively; Starrett Housing Corporation et al. and The Government of the Islamic Republic of Iran, Award No. ITL 32-24-1, 4 Iran-U.S. CTR 122, 143; INA Corporation and The Government of the Islamic Republic of Iran, Award No. 184-161-1, ibid. vol. 8, 373; Oil Field of Texas, Inc. and Government of the Islamic Republic of Iran, Award No. 258-43-1, para. 22, ibid. vol. 12 pp. 308, 314; Mobil Oil Iran Inc. et al. and Government of the Islamic Republic of Iran et al., Partial Award No. 311-74/76/81/ 158-3, para. 46, ibid. vol. 16, 3, 17, and Electronic Systems International, Inc. and Ministry of Defence of the Islamic Republic of Iran, Military Industries Organization, Award No. 430-814-1, para. 51 , ibid. vol. 22 p. 351.

32. For bank account claims see, e.g., Harza Engineering Company and Islamic Republic of Iran, Award No. 19-98-2 Iran-U.S. CTR 499, 504; Tippets, Abbett, McCarthy, Stratton and TAMS-AFFA Consulting Engineers of Iran et al. , Award No. 141-7-2, ibid. vol. 6 pp. 219, 223; Computer Sciences Corporation and Government of the Islamic Republic of Iran et al., Award No. 221-65-1, ibid. vol. 10 pp. 269, 299-300; Training Systems Corporation and Bank Tejerat et al., Award No. 283448-1, para. 24, ibid. vol. 13 pp. 331, 337; Electronic Systems International, Inc., Award No. $430-$ 814-1, loc.cit. n. 31, same para. note 5; Robert $R$. Schott and Islamic Republic of Iran et al., Award No. 474-268-1, para. 47, ibid. vol. 24 p. 219, and paragraph 16 of Award No. 475-114911, Ali Asghar and The Islamic Republic of Iran, ibid., vol. 24 p. 238. For bank guarantee claims see, e.g., paragraph 183 of Award No. 260-308-2 in Combustion Engineering, Inc. et al. and The Islamic Republic of Iran, ibid, vol. 26 p. 110.

33. Paragraphs 16-17 of the General Declaration and Articles II(3) and VI(4) of CSD.

34. The Tribunal has not yet decided the issue, but there are some arguments in favour of the interpretation that the "official claims" (see n. 14) are also excepted from the requirements of outstandingness provided by paragraph 1 of the same Article and paragraph 2 of Article VII, in that there is no reference in Article II (2) to the concept of "outstandingness".

35. See, e.g., Cascade Overview Development Enterprises, Inc. (Refusal Case No. 1), 1 Iran-U.S. CTR 127; Mohammad Sadegh Jahanger (Refusal Case No. 2), ibid., p. 128; Ateyeh Showarai (Refusal Case No. 28), ibid., p. 226; $K$ and $S$ Irrigation Co. (Refusal Case No. 29), ibid., p. 228, and compare them with the contentious decision of the Full Tribunal in Detroit Bank and Trust Company (Refusal Case No. 2), ibid. vol. 2 p. 312. Claimants of the so-called "small claims" (see n. 37, infra) were more fortunate than those of "large claims" (see n. 36, infra) because they have been given a further opportunity to institute their claims, already time-barred, before the United States Foreign Claims Settlement Commission, pursuant to a global settlement reached between the two Governments. See Article III(IV) of the Settlement Agreement attached to the Award on Agreed Terms, n. 37, infra. 
were filed with the Tribunal's Registry, including 965 large claims ${ }^{36}$ and 2,782 small claims ${ }^{37}$ In addition, to date 69 " $\mathrm{B}$ " or official claims and 25 interpretative claims or claims connected with the performance of the Declarations ("A claims") have been filed with the Tribunal.

The subject matter of claims within the jurisdiction of the Tribunal (ratione materiae) is defined by Article II(1) and (2) of the CSD. Paragraph 1 of Article II of the CSD provides:

"An international arbitral tribunal (the Iran-United States Claims Tribunal) is hereby established for the purpose of deciding claims of nationals of the United States against Iran and claims of nationals of Iran against the United States, and any counterclaim which arises out of the same contract, transaction or occurrence that constitutes the subject matter of that national's claim, if such claims and counterclaims are outstanding on the date of this agreement, whether or not filed with any court, and arise out of debts, contracts (including transactions which are the subject of letters of credit or bank guarantees), expropriation or other measures affecting property rights..."38

Certain types of claims are specifically excluded from the Tribunal's jurisdiction. Thus, "claims arising under a binding contract between the parties specifically providing that any dispute thereunder shall be within the sole jurisdiction of the competent Iranian courts" were excluded "in response to the Majles position" ${ }^{39}$ Also excluded are the claims "described in paragraph 11 of the [General Declaration], ${ }^{40}$ and claims arising out of the actions of the United States in response to the conduct in such paragraph." Claims arising out of the contractual arrangements

36. Cases with a relief sought of over U.S. $\$ 250,000$ are called large claims.

37. Cases wherein relief of less than U.S. $\$ 250,000$ is sought are termed small claims. After the resolution of about 444 small claims (decided, terminated by orders or awards, withdrawn, or reclassified), all the remaining small claims were settled, on 22 June 1990, by the Award on Agreed Terms no. 483-Claims of Less than $\$ 250,000 / \mathrm{B} 86 / \mathrm{B} 38 / \mathrm{B} 76 / \mathrm{B} 77-\mathrm{FT}$, pursuant to a global settlement reached between the two governments. (25 Iran-U.S. CTR 327).

38. Emphasis added. For the complete text, see sources referred to in n. 15, supra.

39. See n. 22. To solve the interpretative issues engendered by the provision of this exception and to provide a guideline for future decisions on jurisdiction, the Tribunal selected nine test cases (later known as "Forum Selection Clause Cases") and decided them in full plenary sessions by issuing nine separate Interlocutory Awards. 1 Iran-U.S. CTR 236-325. Notwithstanding the availability of its own Language Section (see n. 62, infra), the Tribunal rendered a number of these leading Awards without properly benefiting from the help and services of that section or any other expert in the Persian language, despite the fact that an investigation into the meaning of certain relevant Persian words was necessary and that the Iranian arbitrators advocated meanings that differed from those understood by the majority through recourse to certain abstract rules of interpretation (see, e.g., ITL 6-159-FT in Ford Aerospace, 1 Iran-U.S. CTR 268). For a detailed analysis of the Tribunal's failure see Watkins-Johnson Company and Watkins-Johnson Ltd. and the Ministry of Defence of the Islamic Republic of Iran and Bank Saderat, Award No. 429-370-1 (dissenting opinion of ASSADOLLAH NOORI, ibid. vol. 22 p. 257, paras 40-62). Against this background the Tribunal embarked, on one occasion, on a detailed analysis of the Persian text of similar provisions in International Technical Products and The Government of the Islamic Republic of Iran (Award NQ 196-302-3), 9 Iran-U.S. CTR 206, 211217. 
between the two Governments, however, are specifically brought within the jurisdiction of the Tribunal by paragraph 2 of Article II of the CSD.

The Tribunal took the position that its jurisdiction ought to be interpreted restrictively. This requirement of restrictive interpretation is mandated, on the one hand, by the well-established rule that the jurisdiction of an arbitral tribunal, whether private or international, emanates from the consent of the parties to the arbitral agreement (an act de compromis or a clause compromissoire) and, therefore, cannot confer "wider jurisdiction than that which was specifically decided by mutual agreement" and, on the other hand, by the settled rule that "no State can, without its consent, be compelled to submit its dispute with other States either to mediation, or to arbitration or to any kind of pacific settlement". ${ }^{4}$

\section{PROCEDURES FOR APPOINTING ARBITRATORS}

The CSD provides that the Tribunal shall consist of nine members or such larger multiple of three as Iran and the United States may agree. ${ }^{43}$ The present composition of the Tribunal (unchanged as to number from the beginning) consists of three members appointed by the Islamic

40. In summary, paragraph 11 of the General Declaration excluded from the Tribunal's jurisdiction all claims arising out of the Embassy event, injuries to persons and properties of the United States and its nationals within the Embassy compound, and "injuries to the United States nationals or their property as a result of popular movements in the course of the Islamic Revolution in Iran which were not an act of the Government of Iran." It was pursuant to the provisions of paragraph 11 of the General Declaration that the United States withdrew its claim pending before the International Court of Justice (no. 1, supra).

41. See, interpretative Case A/2 (decided by the Full Tribunal), 1 Iran-U.S. CTR 101, 103; Case $A / 1$ (Issue II decided by the Full Tribunal), ibid. pp. 144, 152; Case A/16 (United States of America and Iran), Award No. 108-A/16/581/582-FT, 5 Iran-U.S. CTR 57, 60, 70; Alexander Lyons Lianosoff and The Government of the Islamic Republic of Iran (Award No. 104-183-1), ibid. vol. 5, pp. 90, 92-93, and Watkins-Johnson Company (dissenting opinion of A. NOORI), 22 Iran-U.S. CTR pp. 257, 296, and note 43 .

Despite this understanding, and against the decision in Case $A / 2$, the Tribunal interpreted its jurisdiction "very broad[ly]" in deciding other cases (see, e.g., ITL 11-39-2 and ITL 1255-2, 1 Iran-U.S. CTR 487 at 490 and 496; dissenting opinions of SHAFIE SHAFIEI to the same Interlocutory Awards, 3 Iran-U.S. CTR 312; and decision of the Full Tribunal in International Schools Services, Inc., and National Iranian Copper Industries Company (ITL 37-111-FT), ibid. vol. 5, p. 338, to which President LAGERGREN dissented, n. 42 infra.)

42. See, Lillian B. Grimm and The Islamic Republic of Iran, Award No. 25-71-1, 2 Iran-U.S. CTR 78, 80; Award No. 105-B/16-1 (Iranian Customs Administration and The United States of America), 5 Iran-U.S. CTR 94-95; Award No. 106-B/24-1 (The United States of America and The Islamic Republic of Iran), 5 Iran-U.S. CTR p. 99; International Schools Services, Inc., ITL 37-111-FT, loc.cit. n. 41 (dissenting opinion of President LAGERGREN, citing the decision by the PCIJ in the Eastern Carelia Case, Ser. B. No. 5 (1923) p. 27); dissenting opinion of the Iranian Arbitrators in Case A/18,5 Iran-U.S. CTR pp. 287-288, and Watkins-Johnson Company and Watkins-Johnson Ltd., 22 Iran-U.S. CTR p. 296 note 44.

43. See Article III(1) of the CSD. 
Republic of Iran, three by the United States of America, and three third country members either selected by agreement among the partyappointed arbitrators ${ }^{44}$ or, where the latter are unable to agree, by the Appointing Authority as foreseen in the Arbitration Rules of the United Nations Commission on International Trade Law (UNCITRAL) ${ }^{45}$. As one might expect, from the Tribunal's inception it has been difficult for the party-appointed arbitrators to agree on the third country members except for the first three third country arbitrators that were selected by mutual agreement after long debate. ${ }^{46}$

$\operatorname{Iran}^{47}$ and the Iranian arbitrators ${ }^{48}$ have taken the position that in arbitrations before a tribunal which, like the present one, has been established by agreement between two States as equal subjects of international law, the device of recourse to an Appointing Authority is unacceptable because it could eventually lead to the imposition of arbitrator(s) against the will of the States concerned, and is contrary to the

44. These last three arbitrators have always been selected or appointed from among arbitrators of nationalities other than the nationalities of the contracting parties. This was due to the sensitivity of the issues involved and the hostility prevailing between the two Governments from the start of negotiations throughout the period of implementation of the CSD. Article 6(4) of the Tribunal Rules also advises and requires that such considerations be taken into account. As to the party-appointed arbitrators, due to the very sensitive political and economic considerations involved, both Governments found themselves more secure in relying on their own nationals, although nothing would have prevented them from appointing jurists or experts from some other country.

45. For the original UNCITRAL rules and the Tribunal Rules based on them, see, e.g., 1 IranU.S. CTR 57 and 2 Iran-U.S. CTR 405.

46. Judge GUNNAR LAGERGREN (Swedish), a former President of the Court of Appeal for Western Sweden, an eminent figure in international arbitration and President of the Arbitral Tribunal for the [London] Agreement on German External Debts, and also a Judge at the European Court of Human Rights; Judge PIERRE BELLET (French), a distinguished judge and former Chief Justice of France, and Mr. NIIS MANGARD (Swedish), a professional arbitrator. Mr. MANGARD was soon challenged by the Government of the Islamic Republic of Iran and, not having resigned, was declared by the Iranian Agent to the Tribunal as "disqualified" (1 Iran-U.S. CTR 111). Although this challenge was not sustained by Mr. CH. M. J.A. MOONS (the then Chief Justice of the Supreme Court of the Netherlands) sitting as Appointing Authority (ibid. p. 509), the issue lasted as a point of dissatisfaction to Iran and the Iranian members, exasperated further by the belief that Mr. MANGARD remained hostile and maintained a persistent voting record against Iran (see, e.g., "The note of the Iranian members of the Tribunal attached to the Decision of the Full Tribunal in Case A/18", 5 Iran-U.S. CTR p. 266; the statement of Mr. M. M. KASHANI, 7 Iran-U.S. CTR, p. 281 et seq.; RAHMATULLAH KHAN, The Iran-United States Claims Tribunal, Controversies, Cases and Contribution (1990) p. 72; and other documents, 7 Iran-U.S. CTR, pp. 284-288 and 306-316). The tension, which could have been contained by the voluntary resignation of Mr. MANGARD, was finally brought to a head by his somewhat forced resignation when two of the Iranian arbitrators physically prevented him from entering the Tribunal premises on 3 September 1984 (7 Iran-U.S. CTR pp. 281-302, and IALR of 28 September 1984). The Government of the United States challenged both Iranian arbitrators allegedly involved in the act of preventing Mr. MANGARD from entering the Tribunal (7 Iran-U.S. CTR pp. 289-302), but their appointment was withdrawn before any decision on the challenge.

47. See, e.g., letters from Iran's Agent to the Tribunal addressed to the United States Agent dated 24 May and 6 September 1984 ( 6 and 7 Iran-U.S. CTR 300 and 283 respectively). 


\section{rule that no arbitrator can sit in judgement over States without having received their agreement. ${ }^{49}$}

After selecting or appointing three third country arbitrators, the partyappointed arbitrators (or in case of failure of the party-appointed arbitrators to agree, the Appointing Authority) shall appoint one of the third country arbitrators as President of the Tribunal. ${ }^{50}$ The nine members of the Tribunal thus constituted are divided into three panels, each panel forming a Chamber consisting of one Iranian, one American, and one third country member who acts as chairman. ${ }^{51}$ Claims filed with the Tribunal are divided among the Chambers or are allocated to the Full Tribunal for

48. See, e.g., dissenting opinion of MAHMOUD KASHANI to Presidential Order No. 31 dated 21 September 1984, 6 Iran-U.S. CTR 303; statement of the Iranian Arbitrators (7 October 1984) in connection with the 3 September event, ibid. vol. 7 p. 306, and letters dated 17 July and 24 September 1984 by M. M. KASHANI, Iranian Arbitrator, to Chief Justice of the Supreme Court of the Netherlands (the Appointing Authority), reprinted in IALR, 28 September 1984, p. 9.362, and 6 Iran-U.S. CTR 305. The letter of 17 July was not published in the Iran-U.S. Claims Tribunal Reports (Grotius publishers apparently considered the material "defamatory", as explained in their letter dated 21 March 1989 answering the author's inquiry in his capacity as a Ph.D. student of the London School of Economics and Political Science while preparing his article).

49. This being the position, the negotiators should have avoided reference to the UNCITRAL Rules by agreeing on a more satisfactory alternative mechanism, or else they should have limited its application, assuming, of course, that they were aware of the consequences at the time of the negotiations. See, in this connection, letter from the Agent of Iran to the Agent of the United States, reprinted in 6 Iran-U.S. CTR 300.

50. See Article III(1) and (2) of the CSD. The first and the current President of the Tribunal (Judge GUNNAR LAGERGREN, of Sweden and Judge JOSE MARIA RUDA, of Argentina) were appointed by agreement between the party-appointed arbitrators. The other two presidents (Professor CARL H. BÖCKSTIEGEL from the University of Cologne, and ROBERT R. BRINER, a private practitioner in international arbitration (respectively German and Swiss nationals) were appointed by the Appointing Authority against Iran's and the Iranian arbitrators' strong objections (6 Iran-U.S. CTR 303 and IALR 10 February 1989, p. 16897). Professor BÖCKSTIEGEL resigned as of 15 December 1988. Mr. BRINER resigned as of 5 February 1991, after twice being challenged by the Islamic Republic of Iran. The first challenge related specifically to a large oil claim, Amoco Iran Oil Co. and The Islamic Republic of Iran et al. (Case No. 55), 16 September 1988 and 21 October 1988, issue 18. BRINER withdrew from the case on 6 December 1988 (IALR January 1989, p. 16802) before any decision by the Appointing Authority (For a collection of documents pertaining to the first challenge, see 20 Iran-U.S. CTR 175-330). The second challenge was filed by Iran on 28 July 1989 on the ground that he deliberately disregarded the fundamental tenets of adjudicative process in Phillips Petroleum Company Iran and The Islamic Republic of Iran et al. (21 Iran-U.S. CTR 79); MLR of 4 August 1989, Issue 13, p. 3; IALR of 8 August 1989, Issue 14, pp. 17651 et seq; and 15 YCA (1990) 195-197. This challenge was dismissed by Mr. MOONS on 19 September 1989 (Decision served on 21 September), primarily based on Article 11 of the Tribunal Rules for not being timely raised (IALR of 22 September 1989, p. 17808; MLR of 13 October 1989, p. 3). In the course of the second challenge another general challenge was filed by Iran on 11 September 1989 asserting other "improper conduct". This challenge was also denied by the Appointing Authority by his decision dated 25 September 1989 , served on 26 September 1989 (IALR of 5 October 1989, p. 17879 and 15 YCA (1990) p. 197. Documents relating to the second series of challenges reproduced in 21 Iran-U.S. CTR $318,402)$. This time Iran also moved to vacate the English version of the Award No. 425-39-2 in Phillips Petroleum Company Iran by filing Case A/25 (MLR of 1 September 1989 and 21 IranU.S. CTR 283). Case A/25 was later withdrawn and the English version of Award No. 425-39-2 was considered null and void pursuant to the Award on Agreed Terms No. 461-39-2, (IALR of 12 January 1990, 18281 and 18289; MLR of 4 January 1990 and MLR of 12 January 1990); 15 YCA (1990) p. 197 and 21 Iran-U.S. CTR 285, 286. 
decision. ${ }^{52}$ The third country arbitrators play the most important and conclusive role in the Tribunal's decisions. The importance of the thirdcountry arbitrator's role is better appreciated if one considers the fact that, except as to a few issues, the Chambers did not feel obliged to follow the decisions of the other Chambers. Moreover, the rulings varied not only among the Chambers, but have also changed over time within a Chamber following the replacement of the chairman of the Chamber, or within the Full Tribunal, following changes in its composition. ${ }^{53}$ Even in the eyes of two of the third-country arbitrators, one of whom served as the first President of the Tribunal and Chamber of Chamber One and the other as the first Chairman of Chamber Three, this fact and the forceful

51. The present Chairmen of the three Chambers are: (1) Prof. BENGT BROMS (Finland), Professor of the Faculty of Law at the University of Helsinki, representative of Finland in the Sixth Committee of the U. N. General Assembly, head of the Finnish delegation to many legal conferences around the world, member of the Institute of International Law and a member of the Permanent Court of Arbitration in The Hague; (2) Judge JOSE MARIA RUDA (Argentina), a former Rapporteur of the Sixth Committee of the U.N. General Assembly, Chairman of the Argentine delegation to the U.N. General Assembly, ICJ Judge for 18 years and President of the Court before his appointment to replace Mr. BRINER and (3) Professor GAETANO ARANGIO-RUIZ (Italy), Professor of Public International Law at the University of Rome, a member of the Institute of International Law and a member of the United Nations International Law Commission.

52. All of the group " $A$ " cases (such as interpretative cases and claims related to breaches or non-performance of the undertakings under the Accords) and the most important cases of the group " $B$ " cases (official claims, see n. 14) and cases concerned with a common issue are normally decided by the plenary sessions of the Tribunal. All other claims, including some of the group " $B$ " cases, are divided, by lot, among the Chambers.

53. For an example of such an attitude, see the interpretative decision No. 62-A21-FT (Case A) 21, The Islamic Republic of Iran and The United States of America, 14 Iran-U.S. CTR 324), wherein the Full Tribunal found that although "[t]he Tribunal has no authority under the Algiers Declaration to prescribe the means by which each of the States provide for... enforcement" of the Tribunal awards, none the less it is "incumbent on each State Party to provide some procedure or mechanism whereby enforcement may be obtained..." and "[i]f procedures did not already exist as part of the States' legal system they would have to be established." (loc. cit. para. 15). There are many other rulings whereby the Respondent Government was requested to take certain specific action such as preventing the local courts from adjudicating cases filed with the Tribunal, or preventing calls under a particular bank guarantee or standby letter of credit, or to provide for their release (e.g., E.Systems and The Islamic Republic of Iran, ITM 13-388 FT, 2 Iran-U.S. CTR 51; Watkins-Johnson Company and Watkins-Johnson Ltd. 22 Iran-U.S. CTR pp. 218, 256). Contrary to such a precedent, the Full Tribunal, with a different composition in a very recent decision, referred to $A / 21$ and, while citing the first negative sentence as a precedent, stopped short of stating what it had stated in $A / 21$ and did not require the United States to vacate a Treasury Department regulation which the U.S. maintained and continues to maintain in breach of its undertaking, until the time of the Award and to the present date. (See: para. 35 of Interlocutory Award No. 78-A15(IC)-FT (loc.cit. n.14).

Compare also Lillian B. Grimm, Award No. 25-71-1, 2 Iran-U.S. CTR 78, Haji-Bagherpour and The United States (Award no. 23-428-2) 1 Iran-U.S. CTR 38, and Manouchehr Hadadi and The United States, ibid. vol. 8, p. 20, with Alfred L. W. Short (Award No. 312-11135-3) ibid. vol. 16, p. 76, Jack Rankin (Award No. 326-10913-2) ibid, vol. 17, p. 135 and Kenneth P. Yeager (Award No. 324-10199-1) ibid. vol. 17, p. 92. Compare further INA Corporation and The Government of the The Islamic Republic of Iran, Award No. 184-161-1 (separate opinion of Judge LAGERGREN), ibid. vol. 8,373 , at $387-388$, with the decision of the same Chamber in Sola Tiles, Inc. and The Government of The Islamic Republic of Iran, Award No.298-317-1, rendered under the chairmanship of K. H. BÖCKSTIEGEL, 14 Iran-U.S. CTR p. 233. 
dissenting and separate opinions tend to limit the authority of the awards. ${ }^{54}$ It is perhaps because the third country arbitrators were deemed to be the actual decision-makers, that neither of the Governments considered the party-appointed arbitrators to be disqualified because of their past employment or other affiliation with their respective governments. This position has been endorsed by a decision taken by the Appointing Authority in the case of a challenge of an Iranian arbitrator. ${ }^{55}$

\section{AWARDS AND OTHER DECISIONS OF THE TRIBUNAL ${ }^{56}$}

The Accords provide that all awards and decisions of the Tribunal ${ }^{57}$ are final, binding ${ }^{58}$ and enforceable against either of the two Governments in the courts of any nation. ${ }^{59}$ The awards of the Tribunal are not, however, identified as being rendered in any particular country that is party to a convention on recognition and enforcement of arbitral awards, such as the $1958 \mathrm{New}$ York Convention. It is therefore difficult to believe that the municipal courts of a given country will automatically enforce such awards on the strength of the mere reference to their "finality" and "enforceability" in the Accords. ${ }^{60}$ However, the Full Tribunal has ruled, in an Interim Award in E-Systems, Inc., ${ }^{61}$ that at least so far as the courts of the States parties to these Accords are concerned "the Award to be rendered by the Tribunal, which was established by inter-government agreement, will prevail over any decisions inconsistent with it rendered by

54. See Judge LAGERGREEN, Five Important Cases on Nationalization of Foreign Property, published by the Raoul Wallenberg Institute (Report No. 5, Lundo 1988) p. 7; Nils Mangard, book review in 24 Vanderbilt JTL (1991) 597, 609. See also David D. Caron, "The Nature of the IranUnited States Claims Tribunal and the evolving structure of international dispute resolution", 84 AJIL (1990) 104, 105 and note 4.

55. See Appointing Authority's Decision in A. Noori Challenge (IALR, 22 October 1990, p. 19501). Judge GEORGE ALDRICH, one of the United States appointed arbitrators was former Ambassador and had previously served as Senior Deputy Legal Advisor at the State Department (IALR, 1 and 15 May and 5 June 1981, pp. 2874, 2950, 2046). Judge CHARLES N. BROWER, another United States appointed arbitrator, with State Department background, did interrupt his appointment as an arbitrator at the Tribunal temporarily in early 1987 to serve as Deputy Special Counsellor to President REAGAN (see IALR, 23 January 1987, p. 13876.

56 . The Tribunal has generally allowed four rounds of filings: (1) Statement of claim and statement of defence; (2) claimant's reply and respondent's rejoinder; (3) claimant's and respondent's memorial and evidence; and (4) the rebuttals to each other's memorials and evidence. Except for Chamber One for a short period under the chairmanship of Judge BÖCKSTIEGEL in certain cases, all Chambers and the Full Tribunal followed the practice of sequential exchange of filings, giving the last opportunity of say to the respondents.

57. For this purpose, awards and decisions of each Chamber are considered as those of the Tribunal. (See Case A/18, 5 Iran-U.S. CTR 251)

58. See Article IV (1) of the CSD and Article 32 (2) of the Tribunal Rules of Procedure.

59. Para. 17 of the General Declaration and Article IV (3) of the CSD. 
Iranian or United States courts" ${ }^{62}$ Notwithstanding the provisions of the Declarations characterizing the awards as final, binding and enforceable, and apart from the instances mentioned in Articles 35 to 37 of the Tribunal Rules, the Tribunal has indicated, in a number of decisions, that it has an inherent power to re-open a case and reconsider or revise a decision under exceptional circumstances where elements such as fraud, forgery or perjury are present. ${ }^{63}$

The official languages of the Tribunal being Persian and English, all written and oral pleadings of the parties must be prepared and conducted - and all orders, decisions and awards of the Tribunal must be rendered in both languages. Every matter made the subject of an Award must be formulated in precise terms in both languages. ${ }^{64}$

One of the unique and unprecedented features of the Tribunal and one of the special benefits to successful United States claimants, is the cre-

60. An attempt by the Dutch Government to give Dutch nationality to the awards of the Tribunal through drafting legislation regarding "Applicability of Dutch Law to the awards of the Tribunal" (4 Iran-U.S. CTR 305) was abandoned, apparently in the wake of the Iranian Government's vigorous objection and the threat to change the Tribunal venue if the bill was to be passed. See, e.g., the statements by the then President and Prime Minister of Iran and the contents of the letter of the Iranian Agent to the Tribunal addressed to the Legal Adviser's Office of the Netherlands Ministry of Foreign Affairs, reprinted or quoted in 5 Iran-U.S. CTR 428, 405, and IALR of 9 March and 13 April 1984, pp. 8067 and 8248.

In a Swiss arbitration decision in Textron Inc. (USA) and Bell Operations Corporation (USA) v. Islamic Republic of Iran and a judgment rendered by the Court of Appeal of the Canton of Zürich upholding that decision in Plamic Republic of Iran $v$. Textron Inc. (USA) and Bell Operations Corporation (USA) (reprinted in 6 Iran-U.S. CTR 328 and 350, respectively), it has been held that the effect of the Algiers Declarations "must be regarded as limited to courts, institutions and state agencies which are subject to the jurisdiction of the two States in question" (ibid. p. 349 and 354) and that "a treaty does not create any rights or obligations for a third party without the lather's consent" (ibid. p. 354).

61. 2 Iran-U.S. CTR 57.

62. But the U.S. Ninth Circuit Court of Appeal held in Gould Marketing (IALR 3 November 1989, p. 18011) that the awards of the Tribunal are enforceable in the United States under the Federal Arbitration Act and the 1958 Convention on the Recognition and Enforcement of Foreign Arbitral Awards without any reference to such supremacy. On 5 March 1990, the United States Supreme Court denied, without comment, a petition for a writ of certiorari by Gould Inc. to the Ninth Circuit ruling (IALR 26 March 1990, p. 18660). Whatever the motives and irrespective of any international weight that the decision might carry with it, the Ninth Circuit decision provided the Government of the United States a way out of the deadlock created by the Full Tribunal in Case A/21 (14 Iran-U.S. CTR 324).

63. See Henry Morris and The Government of the Islamic Republic of Iran et al. (Decision No. 26-200-1) 3 Iran-U.S. CTR 364, 365; Mark Dallal and The Islamic Republic of Iran et al. (Decision No. 30-149-1) 5 Iran-U.S. CTR 74- 75; Dames and Moore and The Islamic Republic of Iran (Decision No. 36-54-3) 8 Iran-U.S. CTR 107, 117-118; World Farmers Trading Inc. and Government Trading Corporation (Decision No. 93-764-1) and Reza and Shanaz Mohajer Shojaee and The Government of Islamic Republic of Iran (Decision No. 95-273-1). Apart from the problematic lack of the Iranian arbitrator's signature and its incompleteness because of not being filed with Persian text (see n. 62 infra), Award No. 425-39-2 in Phillips Petroleum Company Iran (21 Iran-U.S. CTR p. 50) was the subject of an application for revision before the Full Tribunal "because of being arrived at in violation of due process of arbitral procedure and ordre public international" (Iran's application in Case A/25). The application was later withdrawn (n. 50 su$p r a)$, the real extent of the intended inherent power remained undecided. 
ation, with funds provided by Iran, of a Security Account for securing payment of the awards rendered against Iran ${ }^{65}$ While the Accords contain rhetoric in Articles IV(1) and (3) concerning enforcement of awards in Iran's favour, there is no similar mechanism available to Iran to execute any awards against the Government of the United States and its nationals. Awards against Iran, Iranian entities and instrumentalities are satisfied by payment out of the Security Account shortly after the filing of an Award, upon the issuance of a payment instruction by the President of the Tribunal. Initially one billion dollars was deposited in an account with the N.V. Settlement Bank, a subsidiary of the Netherlands Central Bank (De Nederlandsche Bank N.V.), formed specifically for the purpose of maintaining and administrating the account. The Central Bank of Algeria is entrusted with the role of Escrow Agent, ${ }^{66}$ and Iran undertook to maintain a minimum balance of U.S. $\$ 500$ hundred million in the account until the time that the President of the Tribunal has certified that all the awards against Iran have been satisfied, at which point of time the balance in the account will be transferred to Iran. The Accords state further that "all the funds in the Security account are to be used for the sole purpose of securing the payment of, and paying, claims against Iran in accordance with" the CSD. ${ }^{67}$

64. Articles 17(2) and 32 (note 2) of the Tribunal Rules. Because of these requirements, the Tribunal is fully equipped with a Language Section. The Section also provides simultaneous interpretation into Persian and English during oral presentations at the hearing sessions, and at deliberations or plenary sessions.

65. See, e.g., STEPHEN J. TOOPE, Mixed International Arbitrations, Studies in Arbitration between States and Private Persons (1990) 278-283.

66. Because the negotiations were conducted with the active participation of the Government of Algeria as intermediary, which had "consulted extensively with the two Governments as to the commitments which each of them" was "willing to make in order to resolve the crisis within the framework of four points stated in the Resolution of 2 November 1980 of the Islamic Consultative Assembly of Iran" and which had, as a party to the Accords, declared the "interdependent commitments" made by the two Governments, (see the preamble to the General Declaration, loc.cit. n. 1), Iran expected a more responsible role on the part of the Government of Algeria and its Central Bank. Iran expected that Government and its Central Bank to play an active role in interpreting the Accords and in implementing the undertakings, of the quality and extent of which they were, more than anyone else, aware (see the Statement of 24 April 1984 by the then Prime Minister of Iran, 5 Iran-U.S. CTR 430). Iran sought, with no success, the help of the Algerian Government to intervene in instances where it considered an Award to be against the plain wording of the Accords, against the expectation of Iran which considered the Algerians as a fiduciary to whom the large amount of one billion dollars, plus accrued interest, was entrusted. However, the Government of Algeria and its Central Bank contented themselves with the role of automatically issuing instructions for payment. (Refer, e.g., to IALR of 15 October and 5 November 1982, pp. 5324 and 5511 respectively, of 4 November 1983, p. 7370 and of 14 August 1987, p. 14574). 
Despite the fact that, except for a few cases, ${ }^{68}$ the bulk of the claims before the Tribunal were filed by United States nationals, the costs and expenses of the Tribunal are shared equally by the two Governments. ${ }^{69}$

\section{THE TRIBUNAL'S NATURE}

Whether the Tribunal can be characterized as an international tribunal established to decide claims of Governments and/or those of their nationals espoused by them, has been a point of dispute in many instances, particularly in relation to the dual national cases and in the so-called "small claims". The Parties to the Algiers Accords thought that characterization of the Tribunal would affect the applicable law and thus the treatment of the claims. Iran characterized the Tribunal as an international (interState) tribunal and argued that the fact that the Accords permitted individual claimants to present their claims was solely intended to facilitate the processing of those claims before the Tribunal. ${ }^{70}$ Iran also took the position that the claims of individuals are espoused by the respective Governments of those individuals and, as a consequence, the claims of dual nationals with Iranian and United States nationality could not be brought before such an international tribunal by either of the States as being precluded by the principle of the equality of States, and the principle of non-responsibility of a State under international law for the treatment of its own nationals. As to the applicable law, Iran's position is that although normal choice of law rules apply to the underlying private contracts and transactions, the rules of public international law on State

67. For a detailed analysis of the provisions of the Accords and other agreements related to the Security Account, refer to the Decision of the Full Tribunal, and Concurring and Dissenting Opinions rendered in Case A/I, 1 Iran-U.S. CTR 145-149 and 189-214. In this Decision the Full Tribunal ruled that interest must be credited as it accrues to a separate interest-bearing account in the N.V. Settlement Bank until the time that any remaining balance in the Security Account is returned to Iran. As a matter of fact the interest so accrued is only used to replenish the Security Account (ibid. p. 192).

68. Including " $\mathrm{B}$ " claims, among them one of the largest claims against the United States of America for the pre-revolution sale and purchase of arms and ammunition.

69. Article VI (3) of the CSD. The fact is that the United States Government regains all or at least the major part of its costs by "skimming off" 1 or 1.5 per cent (depending on the amount awarded) from the judgments in favour of United States' claimants.

70. See, e.g., Iran's position as summarized in the Decision of the Full Tribunal in Case A/18, 5 Iran-U.S. CTR pp. 251, 254-256; dissenting opinion of Iranian arbitrators in the same case, p. 275, at 291 et seq.; concurring/dissenting opinion of A. NOORI to Award No. 360-10514-1 in Leonard and Mavis Daley (a claim of less than US $\$ 250,000$ presented by the United States of America) and The Islamic Government of Iran, 18 Iran-U.S. CTR 244, 245; separate opinion of SAYED KHALIL KHALILIAN in Lord Corporation and Iran Helicopter Support and Renewal Company, Award No. 346-10973-2, ibid. pp. 377, 382, and dissenting opinion of A. NOORI in WatkinsJohnson Company and Watkins-Johnson Ltd., 22 Iran-U.S. CTR 257. 
responsibility should apply to any findings against the Governments and agencies and/or instrumentalities involved.

The position taken by the United States, on the other hand, appears difficult to reconcile. In many instances during the early stages of the Tribunal's work, the United States argued that the Tribunal was created by treaty and therefore "a creature of international law, and its decisions are part of international law... not part of domestic law", 71 and that the Government was presenting claims "in continuance of the exercise of diplomatic protection of its nationals, acting as parens patriae, trustee, guardian and representative, and on their behalf. ${ }^{72}$ By the time of the proceedings in Case A/18, the Government of the United States adopted the position that "the general character of the Tribunal does not support Iran's position that the Tribunal's function is the exercise by States of diplomatic protection" and that "Iran's assumption concerning the nature of the Tribunal is unfounded."73

Referring to the Panevezys-Saldutiskis Railway Case ${ }^{74}$ the Full Tribunal found in Case $A / 18$, that:

While this Tribunal is clearly an international tribunal established by treaty and while some of its cases involve disputes between the two Governments and involve the interpretation and application of public international law, most disputes (including all those brought by dual nationals) involve a private party on one side and a Government or Government-controlled entity on the other, and may involve primarily issues of municipal law and general principles of law. In such cases it is

71. Statement of the United States Agent (ARTHUR ROVINE) in the hearing of 10 January 1983, in E-Systems, Inc. and The Islamic Republic of Iran.

72. Page 1 of the Statement of Claim in the Sample Case, The Government of the Unites States of America on behalf and for the benefit of its nationals v. The Islamic Republic of Iran, Case No. 86. In the 64th session of the Full Tribunal, held on 5 November 1982, the same Agent took the position that owing to the nature of these claims as espoused claims, in bringing claims before this Tribunal "no instructions were being sought or received from individual claimants". See, dissenting opinion of A. NOORI in Leonard and Mavis Daley, 18 Iran-U.S. CTR p. 246 note 5 . In the capacity as "parens patriae, trustee, guardian and representative" of the Claimants, Mr. JOHN CROOK, the United States' Agent who replaced Mr. ROVINE, did consider himself entitled to intervene in the settlement negotiations if the Security Account or position of other Claimants was, in his view, at stake. During the drafting of a settlement with two major oil companies wherein the author was directly involved, the American agent tried hard to prevent the Claimants involved from agreeing with the conditions which, on their face, showed that the money paid from the security account would ultimately be used, in addition to other funds, to satisfy the National Iranian Oil Company's counterclaims for crude oil sold and supplied. See, e.g., the awards on Agreed Terms Nos. 208-73-3 and 209-78-3 in Iran Chevron Oil Company and the Government of The Islamic Republic of Iran and National Iranian Oil Company, and Transocean Gulf Oil Company and Government of The Islamic Republic of iran and National Iranian Oil Company, 10 Iran-U.S. CTR 357 et sep.; IALR, 24 January 1986, pp. $11813,11836,11845 ; 1$ MLR, Issue No. 48, 17 January 1986, pp. 3340, 3649; and JOHN CROOK's letter dated 6 January 1986 to the Iranian Agent and the reply of the Iranian Agent dated 9 January 1986.

73. Decision in Case A/18, 5 Iran-U.S. CTR p. 258.

74. PCIJ Sec. A/B No. 76. 
the rights of the Claimant, not of his nation, that are to be determined by the Tribunal. ${ }^{75}$

The premises on which the Full Tribunal's conclusion is drawn are not plausible. The assumption of the Tribunal seems to be that municipal law and general principles of law would only apply where a private party is a claimant. No case involving individuals can be decided, even in espousal claims, by mere reference to public international law. On the other hand, application by a tribunal of general principles of law or the municipal law of a given country will not deprive it of its international (inter-State) character. To argue the contrary would seem to be inconsistent with the precedents established before both the Permanent Court of International Justice in the Serbian and Brazilian Loans Cases ${ }^{76}$ and its successor the International Court of Justice in the Barcelona Traction Case.$^{77}$ In these cases the Courts applied general principles of private law and yet their international character can not be doubted. The Iran-U.S. Claims Tribunal also found it appropriate to apply, as an international tribunal, general principles of law as "rules or principles codified or judicially recognized in the great majority of the municipal legal systems of the world" that are widely accepted and applied by such tribunals. ${ }^{78}$ In fact by assimilating its character to that of the International Court of Justice in Barcelona Traction Case, ${ }^{79}$ the Full Tribunal created a de facto successorship legal principle by deriving the rule "from principles of international law applicable in analogous circumstances or from general principles of law", in a situation wherein the circumstances did not, to the Tribunal's own judgement, fall "within well developed and discussed doctrines of law". 80

75. 5 Iran-U.S. CTR p. 261. It is worth noting that the Tribunal in this case was dealing with issues ("nationality and dual nationality") purely from the public international law view, and tried to resolve the case on the basis of rules of international law and precedents established by international fora, including those by the International Court of Justice and its predecessor. Moreover, the award itself refers to the "international" character of the Tribunal at the start of this part of its argument. In other awards rendered after the decision in $A / 18$ Case, the Tribunal stated, very plainly, that "it has a specific international character" (BendoneDerossi International and The Government of the Islamic Republic of Iran, Award No. ITL 40-3751, 6 Iran-U.S. CTR, 130,132) and that "the Tribunal is a truly international tribunal which, as such, is concerned with the rights and duties of States in public international law." (Mobil Oil Iran Inc. et al., 15 Iran-U.S. CTR 23 (para 66)).

76. Both decided in 1929, PCIJ Ser. A Nos. 20/21, 16-49 and 101-126.

77. Barcelona Traction, Light and Power Company Limited (Belgium v. Spain), ICJ Rep. 1970 p. 4.

78. Sea-Land Service Inc. and Government of the Islamic Republic of Iran, Award No. 135-33-1, 6 Iran-U.S. CTR 149, 168. See also Benjamin R. Isaiah and Bank Melat, Award No. 35-219-2, ibid. vol. 2 pp. 232, 237; T.C.S.B., Inc. and The Islamic Republic of Iran, Award No. 114-140-2 ibid. vol. 5, 160, 171-2; DIC of Delaware Inc. et al. and Tehran Redevelopment Corporation et al., Award 176-255-3, ibid. vol. 8 pp. 144-161 and Questech. Inc. and The Ministry of National Defence, Award No. 191-59-1, ibid. vol. 9 pp. 107, 122-123.

79. Supra n. 77. 
There can be little doubt that the Tribunal is an international institution established by two sovereign States through the mediation of another sovereign State - the Democratic and Popular Republic of Algeria - and subject to public international law. The Accords by their plain terms state that the Tribunal is established as "an international arbitral tribunal ${ }^{n}{ }^{81}$ This is further established by the fact that the Accords were negotiated, and the Tribunal was established with the intent to settle international disputes existing between the two adhering States and to resolve a number of inter-State disputes including the purely public international law issue with which the International Court of Justice was dealing just prior to the entry into force of the Accords and the release of several billion dollars in Iranian assets and properties. Moreover, the States parties to the Accords acted in their international capacity by espousing the claims of their nationals for the benefit of these nationals, and it should be noted that the proceeding in Case $A / 18$ can be seen as involving a defence by the Government of the United States of the principle of espousal of claims. In that case the U.S. argued that a number of claimants who alleged that they had both Iranian and United States nationality had the right to bring claims before the Tribunal, so that the United States was in fact "espousing" those claims. ${ }^{82}$

It was on the basis of this right that the Supreme Court of the United States upheld ${ }^{83}$ the President's power to settle claims on United States nationals' behalf or to bar them from prosecuting their claims against Iran. ${ }^{84}$ In light of the unique situation of the Tribunal, however, and because of the thousands of very complex and complicated claims filed there, the States parties did agree to allow the claimants seeking over U.S. $\$ 250,000$ to present their claims in person to facilitate the Tribunal's task. ${ }^{85}$ Otherwise, as was the case with the small claims, the claims would have been presented by the respective Government of each such national. $^{86}$

80. ITL 10-43-FT, Oil Field of Texas, Inc. and The Islamic Republic of Iran et al., 1 Iran-U.S. CTR 347,361 .

81. Article II para. 1 CSD.

82. "It should be reiterated that the point of the exercise was that... the nationality of claims rules did apply and it was necessary to show that individual claimants had a right to the protection of one of the State parties, a protection operating through the grant of access to the Tribunal." TOOPE, op.cit. n. 65, p. 303 (emphasis added).

83. Dames and Moore v. Reagan, loc.cit. n. 18 pp. 679-680.

84. See, para. 11 of the General Declaration.

85. See, IAN BROWNLIE, Principles of Public International Law (1981), p. 578; and DAVID LLOYD JONES, "The Iran-United States Claims Tribunal: Private Rights and State Responsibility", 24 Va JIL (1984) pp. 259, 266 (note 30) and 276. 


\section{THE APPLICABLE LAW}

Whatever the outcome of the discussions on its nature, the fact is that the Tribunal has not been established by contractual agreement between individuals or governmental entities, and does not derive its authority from their will, but has instead been established by inter-governmental agreement and is therefore subject to international law. ${ }^{87}$ The law to be applied by the Tribunal can be viewed from three different perspectives: (1) the law applicable in interpreting the terms and conditions of the Accords including the Governments' performance of each of them; (2) the law to be applied in deciding claims brought by a national of one State against the Government of the other, or in deciding officials; and 3) the procedural law.

By characterizing the Algiers Declarations as a treaty, the Tribunal has ruled unequivocally that the interpretation of the Accords is governed by the rules and principles of public international law. ${ }^{88}$ Accordingly it has applied the rules of treaty interpretation to determine the meaning of terms, conditions and wording of the Algiers Declarations. ${ }^{89}$ In deciding inter-governmental disputes and official claims, emphasis has been placed on the Tribunal's mandate to "decide all cases on the basis of respect for law" ${ }^{90}$ This being the case, the Tribunal is barred from taking decisions as amiable compositeur or ex aequo et bono. Moreover, as is clearly stated in Article 33(2) of the Tribunal Rules, the Tribunal is, absent express written authorization by the arbitrating parties, prevented from basing its decisions on such rules. ${ }^{91}$ While the Tribunal must look to rules of law, given the variety of issues raised by the cases before it, the Tribunal is called upon to choose from among categories of rules of law to decide those issues. ${ }^{92}$ Generally the Tribunal has to apply two main categories of legal rules. First, rules of private law including princi-

86. Article III (2) of the CSD. In Parguin Private Joint Stock Company and United States of America (decision of 20 December 1983), 4 Iran-U.S. CTR 210, Chamber Three found it to be unjustifiable to dismiss a small claim purely on the ground that it was filed "without the Claimant being represented by the Government" at the time of filing. For more arguments on the whole issue, see DAVID LLOYD JONES, loc.cit. n. 85.

87. Anaconda-Iran, Inc. and The Government of the Islamic Republic of Iran et al., ITL 65-167-3, 13 Iran-U.S. CTR 199, 223.

88. In this respect reference may be made to almost all interpretative and other decisions rendered in connection with performance disputes between the two Governments party to the Algiers Declarations, e.g., 1-A/2-FT, 1 Iran-U.S. CTR 104; Full Tribunal Decision in Case A/1 (Issue I 1 Iran-U.S. CTR 189; Nasser Esphahanian and Bank Tejerat (Award No. 31-157-2), ibid. vol. 2 pp. 175, 160-161; A/18, 5 Iran-U.S. CTR 251; International Schools Services and Iranian Copper Industries, ITL 37-111-FT, ibid. vol. 5 p. 338; Burton Marks and Harry Umann, ibid, vol. 8, 290; ITL 63-A/15(IG)-FT, 12 Iran-U.S. CTR p. 40; DEC 62-A/21-FT, ibid. vol. 14 p. 324; Award No. 382-B/1 (Claim 4)-FT, ibid. vol. 19, 273 and Para. 26 of ITL 78-A/15(I-C)-FT, IALR, May 1992, p. 20849. 
ples of commercial law and usages of trade; and second, rules and principles of international law. In determining the proper law applicable to a given dispute, the Tribunal should in principle respect the agreement of the parties as reflected in the provisions of the relevant contracts and transactions (whether public or private) and apply the appropriate choice of law rules. ${ }^{93}$ To judge from the Award in Anaconda-Iran Inc. ${ }^{94}$ it would seem that the Tribunal is vested with such broad freedom of discretion as to be able to disregard not only the law determined to be applicable by such well-settled rules and principles as lex loci contractus, lex

89. It is hard to criticize the Tribunal for applying such rules of interpretation. Yet, in circumstances such as those of the Algiers Declarations, application of the "plain meaning" or "common intent" rules might not necessarily be a reliable guide to the real intention of the parties. Here the entire negotiation process was conducted indirectly. The representatives of the United States possessed a vast amount of legal and historical experience in the field of mixed, general or special claims commissions or tribunals. By contrast, the Iranian negotiators had little practical experience in law and no experience with these sorts of agreements and therefore were not at an equal bargaining level with their American counterparts (see, e.g., Rahmatullah Khan in supra $\mathrm{n}$. 46). So much so that, as we have seen in supra $\mathrm{n}$. 29, they had confused the meaning of counter-claim with that of claims that Iranian Government entities and organizations had in turn against United States nationals. The Tribunal did not, and as a matter of fact could not, by resorting to the rules of interpretation, accept the sincere explanation of the Iranian negotiators that the phrase "whether or not filed with any court" in paragraph 1 of Art. II of the CSD was proposed by them "to merely protect and secure the position of Iran by providing for the Iranian ministries and organizations the possibility of referring their respective disputes against the United States corporations to the Arbitral Tribunal" since those Iranian entities "had not previously filed their claims with any court". Yet the Tribunal used the same phrase against Iran to expand its jurisdiction to claims not previous filed with any court, although the prime reason for adhering to the CSD (as is contemplated in Principle " $\mathrm{B}$ " of the General Declaration, see supra $\mathrm{n}$. 25) was to vacate the attachments and to terminate the claims already filed against Iran (See Interlocutory Awards Nos 11 and 12 in Phillips Petroleum Co. and Amoco Iran Oil Co., loc.cit. n. 23, pp. 491-2 and 497). All this occurred because the United States negotiators, cleverly enough, placed the phrase where it best suited them. Therefore, to talk about a common intention of the parties is, in many ways, a mockery.

90. Article V of the CSD provides: "The Tribunal shall decide all cases on the basis of respect for law, applying such choice of law rules and principles of commercial and international law as the Tribunal determines to be applicable, taking into account relevant usages of the trade, contract provisions and changed circumstances."

91. Article 33 (2) provides that "[t]he Tribunal shall decide ex aequo et bono only if the arbitrating parties have expressly and in writing authorized it to do so". Despite this clear mandate, Chamber Two of the Tribunal ruled that the Tribunal's "search is for justice and equity". CMI International, Inc. and Ministry of Roads and Transportation (Award No. 99-245-2), 4 IranU.S. CTR 263, 268. Chamber One, with Judge LAGERGREN as Chairman, also felt free, in a couple of cases, to base certain of its findings on the rules of equity. See Foremost Tehran, Inc. et al. and The Government of The Islamic Republic of Iran et al. Award No. 220-37/231-1, 10 IranU.S. CTR 229, 240.

92. CMI International Inc., loc.cit. n. 91, pp. 267-268; and Anaconda-Iran Inc., loc.cit., n. 87, pp. $199,232$.

93. See, e.g., White Westinghouse Int'l Co. and Bank Sepah-Iran, New York Agency (Award No. 7-14-3), 1 Iran-U.S. CTR 169, 171; Economy Forms Corporation and The Government of The Islamic Republic of Iran (Award No. 55-165-1), ibid. vol. 3 pp. 42, 47-48; Harnishfeger Corporation and Ministry of Road and Transportation et al. (Award No. 144-180-3) ibid. vol. 7 pp. 90, 99; DIC of Delaware, Inc. et al. and Tehran Redevelopment Corporation et al.,ibid. vol. 8, 161-166 and Ali Ashgar, ibid. vol. 24, p. 238.

94. Paras 127-134 of ITL 65-167-3, Anaconda-Iran Inc., 13 Iran-U.S. CTR 231-232. 
loci solutionis, lex rei sitae or the law of the contracting State, but even to disregard the choice of law provisions of the relevant contract when deciding the validity and scope of a contractual term. Although the Tribunal appears to have derived such a power from the phrase "as the Tribunal determines" contained in Article V of the CSD, the Anaconda decision should be limited to the particular context of that case where the claimant had himself argued that the relevant contract was "self-sufficient under all circumstances and that no law shall govern" the contract. Any other interpretation of the Anaconda decision would lead to an incorrect interpretation of Article $V$, and thus to inadequate attention being paid to the actual terms of that Article, in particular where the phrase "as the Tribunal determines" has been used. Moreover, although similar provisions are contained in Article 13 (3) of the rules of the ICC Court of Arbitration $^{95}$ - which provides that "the arbitrator shall apply the law designated as the proper law by the rules of conflict which he determines appropriate" - and in Article 28 of the UNCITRAL Draft Model Law on Arbitration ${ }^{96}$ which provides that "failing designation by the parties, the arbitral Tribunal shall apply the law determined by the conflict of laws, rules which it considers applicable ${ }^{n}$ - no one has interpreted these provisions to empower the arbitrator(s) to disregard completely choice of law rules and contractual provisions. Such broad freedom in applying the law would be tantamount to giving the arbitral body the power to re-write the contract and/or the relationship of the parties in a way completely alien to what the latter had intended.

There are, of course, issues that cannot be decided unless the underlying private law relationship or transaction is determined. Such cases would include claims for debts between private parties arising out of negotiable instruments or out of invoices issued for services rendered pursuant to a contract. In such circumstances, the Tribunal must first search for the proper law to apply in deciding the validity of the transaction if this is disputed and in interpreting the intent of the parties thereto. In cases involving State responsibility, however, the Tribunal must apply international law and general principles of law when it reaches its decision on liability, quantum of damages and compensation, ${ }^{97}$ unless the contract provided for a particular, legally acceptable, standard. ${ }^{98}$

95. 28 ILM (1989) p. 231.

96. 24 ILM (1985) p. 1302.

97. "[T] $]$ he Tribunal may often find it necessary to interpret and apply treaties, customary international law, general principles of law and national laws... With respect to the assessment of damages, the Tribunal considers its main task to be determining what are the losses suffered by the Claimant and to award compensation therefor... the Tribunal prefers to analyze the damage questions in accordance with general principles of law". (CMI International Inc., 4 Iran-U.S. CTR p. 268). 
There are also issues that must clearly be decided under public international law, such as disputes relating to dual nationality and proof of nationality, ${ }^{99}$ or issues involving State responsibility for expulsion, ${ }^{100}$ expropriation or similar measures. ${ }^{101}$

The third group of rules consists of procedural rules to be applied by the Tribunal in conducting its business. As established by paragraph 2 of Article III of the CSD, the Tribunal is required to apply the "arbitration rules of the United Nations Commission on International Trade Law (UNCITRAL)" to its procedures "except to the extent modified by the parties or by the Tribunal". After long debate, and in most instances over the dissent of the Iranian Arbitrators, the Full Tribunal adopted its provisional procedural rules on 10 March 1982 . These rules are modeled after the UNCITRAL rules but implement changes, mutatis mutandis, to make them compatible with the provisions of the Algiers Declarations. The Final Tribunal Rules of Procedure were eventually adopted on 3 May 1983. ${ }^{102}$

\section{CONCLUSION}

The foregoing comments address some salient aspects of the Tribunal's work, while making no attempt to deal in depth with the many com-

98. Panguin Private Joint Stock Company (Award No. 275-12783-3), 13 Iran-U.S. CTR 261; Ultrasystem Inc. and The Islamic Republic of Iran and ISIRAN (Award No. 27-84-3), 2 Iran-U.S. CTR 100, 106-107, 110, 116-118; R.N. Pomeroy and The Government of the Islamic Republic of Iran (Award No. 50-40-3) ibid. pp. 372, 383-384; AHFI Planning Associate, Inc. and The Government of Iran et al. (Award No. 234-179-2), ibid. vol. 11 pp. 168, 178; Richard D. Harza et al. and The Islamic Republic of Iran (Award No. 232-97-2), ibid. vol. 2, pp. 76, 105, 107, and R.J. Reynolds Tobacco Co. and The Government of Iran, Iranian Tobacco Company (Award No. 143-35-3), ibid. Vol. 7 pp. 55,60 .

99. Order filed on 20 December 1982 in Flexi-Van Leasing, Inc. and The Islamic Republic of Iran, 1 Iran-U.S. CTR 455 and dissenting opinion of M. M. KASHANI regarding the same Order, ibid. p. 463; Nasser Esphahanian, 2 Iran-U.S. CTR pp. 161-164, and Full Tribunal Decision in $A / 18$ Case, 5 Iran-U.S. CTR 251. For standing of partners in a partnership, see Housing and Urban Services Int'l Inc. and Tehran Redevelopment Corporation (Award No. 201-174-1), ibid. vol. 9 p. 313.

100. See, e.g., Alfred L. W. Short (Award No. 312-11135-3); Jack Rankin (Award No. 326-109132) and Kenneth P. Yeager (Award No. 324-10199-1), Iran-U.S. CTR vol. 16 p. 76, vol. 17 p. 135 and vol. 17 p. 92 respectively.

101. See, e.g., Benjamin R. Isaiah and Bank Mellat, 2 Iran-U.S. CTR 237; American International Group Inc. and The Islamic Republic of Iran (Award No. 93-2-3), 4 Iran-U.S. CTR 96; Sea-Land Service, Inc., 6 Iran-U.S. CTR 149; INA Corporation and The Government of the Islamic Republic of Iran (Award No. 184-161-1) 8 Iran-U.S. CTR pp. 373, 377-379; Separate opinion of Judge LAGERGREN in INA Corporation, ibid. p. 385; Amoco International Finance Corporation and The Government of the Islamic Republic of Iran et al. (Award No. 310-56-3), ibid. vol. 15 pp. 189, 214229, and Mobil Oil Iran Inc. et al. and The Government of the Islamic Republic of Iran et al. (Award No. 311-74/76/81/150-3) 16 Iran-U.S. CTR pp. 20-28.

102. For the Provisional and Final Rules adopted by the Tribunal, see Iran-U.S. CTR vol. 1 p. 57 and vol. 2 p. 405. 
plexities of its mandate. The juridical nature of the Algiers Accord, the limits of the Tribunal's jurisdiction, the procedure for appointing arbitrators, the "Security Account" as a mechanism for securing payment of awards against one of the parties to the Accords, whether the Tribunal is an "international tribunal" arbitrating between States extending diplomatic protection to their nationals or whether, in determining the rights of private claimants, the Tribunal somehow lost its international character and, finally, the law to be applied by the Tribunal, are among matters that are likely to generate considerable discussion among scholars in the future. On 30 June 1991 the Iran-United States Claims Tribunal completed 10 years of work. With all claims of less than $\$ 250,000$ removed from the roll following arbitration of a few of them and negotiated settlement of the rest, and only some one hundred claims remaining to be dealt with, it would appear that the Tribunal should, within a relatively short period, be able to bring its work to a close. That this anniversary went unmarked in any way by the two Governments reflects a general wariness on their part of making any overall evaluation of what the process has meant to them in financial, economic, and ultimately, political, terms. Any such evaluation would be premature, and scholars are likely to argue for many years about the weight and durability of the Tribunal's contribution to legal analysis, the elucidation of legal concepts, and the degree to which distributive justice might have been served through its hundreds of awards, not to mention the dissenting, concurring or separate opinions. It would be difficult to deny, however, that in the course of adapting the UNCITRAL Arbitration Rules and applying them in many hundreds of cases, the Tribunal has explored the intricacies of the international arbitral process itself to an extraordinary, perhaps unprecedented, degree.

It is to be hoped that this expensive, but instructive experience will provide valuable insights for other States when choosing inter-State arbitration as the means of resolving their differences. 